Reserve your space at the AATS Annual Meeting, register for the High Performance Teams in the Operating Room and purchase your ticket for the Special Reception at www.aats.org/annualmeeting/Registration-and-housing

\section{Target Audience}

The AATS Annual Meeting is specifically designed to meet the educational needs of:

- Cardiothoracic Surgeons

- Physicians in related specialties including Cardiothoracic Anesthesia, Cardiology, Pulmonology, Radiology, Gastroenterology, Thoracic Oncology, and Vascular Surgery

- Fellows and Residents in Cardiothoracic and General Surgical training programs

- Nurses, Physician Assistants, Perfusionists, and Allied Health Professionals involved in the care of cardiothoracic surgical patients

- Medical students with an interest in cardiothoracic surgery

\section{AATS Annual Meeting Accreditation}

The American Association for Thoracic Surgery is accredited by the Accreditation Council for Continuing Medical Education to provide continuing medical education for physicians.

The American Association for Thoracic Surgery designates this educational activity for a maximum of 35 AMA PRACategory 1 Credit $(s)^{\mathrm{TM}}$. Physicians should only claim credit commensurate with the extent of their participation in the activity.

For additional information please visit www.aats.org or contact:

American Association for Thoracic Surgery

900 Cummings Center

Suite 221-U, Beverly, MA, USA 01915

Telephone: +1 (978) 927-8330

Fax: + 1 (978) 524-8890

E-mail: meetings@aats.org

\section{AATS Meetings and Sponsored Events www.aats.org}

May 5-6, 2011

Mitral Conclave

Sheraton New York Hotel and Towers

New York, New York

May 7-11, 2011

AATS 91st Annual Meeting

Pennsylvania Convention Center

Philadelphia, Pennsylvania
May 26, 2011

AATS/ASCVTS Postgraduate Course*

Hilton Phuket Arcadia Resort \& Spa

Phuket, Thailand

September 8-10, 2011

International Society for Rotary Blood Pumps Annual

Meeting*

Marriott Downtown

Louisville, Kentucky

October 13-15, 2011

2011 Heart Valve Summit: Medical, Surgical, and Interventional Decision Making

JW Marriott Chicago

Chicago, Illinois

October 20-21, 2011

7th Triennial Brigham Cardiac Valve Symposium*

Fairmont Copley Plaza Hotel

Boston, Massachusetts

*Co-sponsored by AATS.

\section{AATS Online Award Applications}

Now Available at www.aats.org, Deadline: July 1, 2011

David C. Sabiston Research Scholarship 2012-2014 provides an opportunity for research, training, and experience for North American surgeons committed to pursuing an academic career in cardiothoracic surgery.

- Research program must be undertaken within the first three years after completion of an approved North American cardiothoracic residency.

- Applications for the scholarship must be submitted during the candidate's first two years in an academic position.

- The scholarship will begin July 1, 2012, and conclude on July 1, 2014.

- The Scholarship provides an annual stipend of $\$ 80,000$ per year paid to the host institution for direct salary support and related research expenses

Deadline: July 1, 2011

Evarts A. Graham Memorial Traveling Fellowship, 2012-2013 grants support for training of international surgeons who have been regarded as having the potential for later international thoracic surgical leadership.

- Candidate must be a non-North American who plans a cardiothoracic surgery training program in a North American center and who has not had extensive (exceeding a total of six months in duration) clinical 